\title{
Embodied Energy \& Cost Issues of Tank-Bed-Lime Based Geopolymer Adobes
}

\author{
T. K. Jyothi' ${ }^{1}$ B. N. Varsha ${ }^{2 *}$, S. Raghunath ${ }^{3}$, K. S. Jagadish ${ }^{4}$ \\ ${ }^{1}$ Department of Civil Engineering, Government Engineering College, Ramanagara, India \\ ${ }^{2} \mathrm{BMS}$ College of Engineering, Bengaluru, India \\ ${ }^{3}$ Department of Civil Engineering, BMS College of Engineering, Bengaluru, India \\ ${ }^{4}$ Indian Institute of Science, Bengaluru, India \\ Email: jyothi271016@gmail.com, *varsha.bhushana@gmail.com,raghunath.smrc@gmail.com,jagadishks@gmail.com
}

How to cite this paper: Jyothi, T.K., Varsha, B.N., Raghunath, S. and Jagadish, K.S. (2017) Embodied Energy \& Cost Issues of Tank-Bed-Lime Based Geopolymer Adobes. Open Journal of Energy Efficiency, 6, 128139.

https://doi.org/10.4236/ojee.2017.63010

Received: August 11, 2017

Accepted: September 24, 2017

Published: September 27, 2017

Copyright $\odot 2017$ by authors and Scientific Research Publishing Inc. This work is licensed under the Creative Commons Attribution International License (CC BY 4.0).

http://creativecommons.org/licenses/by/4.0/

\begin{abstract}
It is well-known that a product or a system is sustainable if it is economically viable, socially acceptable and environmentally friendly. Load bearing masonry is one such example which is quite sustainable, especially if the masonry units are locally available. It is important to quantify the environmental benefits and cost, if an alternative to an existing technology is to be suggested. Of course the issues related to acceptance have to be discussed and addressed. This paper presents the quantification of embodied energy and cost of limepozzolana-cement (LPC) geopolymer based masonry units made using locally available bulk ingredients viz. tank-bed soil (TBS) and brick-powder (BP). The masonry adobe units developed have achieved the target performance in terms of strength, low water absorption and relative ease of production. Simultaneously the issues related to cost are also discussed in this paper. The studies have revealed that the bulk contributor to embodied energy and cost of geopolymer adobes are the alkaline materials viz sodium hydroxide and sodium silicate. However, the embodied energy and cost per unit strength appears to be better than that of conventional table moulded bricks in south India, especially when alkaline solution at $2 \mathrm{M}$ concentration is used with LPC.
\end{abstract}

\section{Keywords}

Geopolymer Bricks, Embodied Energy, Lime-Pozzolana Cement, Cost

\section{Introduction}

Davidovits [1] proposed that an alkaline liquid could be used to react with sili- 
con ( $\mathrm{Si}$ ) and aluminium (Al) in a source material of geological origin such as kaolinite, clays, etc., or byproduct materials such as fly-ash and rice husk ash to produce binders. As the chemical reaction that takes place in this case is polymerisation process, he coined the term "geopolymer" to represent these binders. The choice of source materials for making geopolymer depends on factors such as availability, cost, etc. Usually sodium or potassium-based solutions are used as alkaline liquids. There is abundant quantum of raw materials consisting of siliceous and argillaceous materials which have the potential of being utilised for the production of "geopolymer" masonry blocks. The "abundant" availability of raw materials, in this paper, refers to tank-bed-soil deposits, which can be seen in plentiful, especially in south India. Lime is another raw material which is abundantly available naturally. Another source of raw material for production of GP-based units is from debris of buildings, which contains huge quantity of bricks. The bricks from construction and demolition waste can potentially be used for production of GP-based units. Another significant reason for the present research is that the strength requirement for masonry block is not as much as that of, say, conventional concrete. Indeed, for low-rise masonry buildings (up to 4 storeys or thereabouts), unit strengths in the order of 5.0 to 10.0 $\mathrm{MPa}$ would suffice. The present study focuses on the issues related to energy and cost on production geopolymer adobes, an alternative to conventional masonry units. The choice of materials/process has been derived based on the basic requirements for masonry units and binders. The need for using locally available materials and a relatively easy process at low level of energy input has provided the motivation for the present work. The fact that many of the raw materials stated earlier are abundantly available is another reason to look at the production of geopolymer-lime-pozzolana-tank-bed-soil-brick-powder-based masonry products. Indeed, this approach is scantly researched. In the present research work, all the raw materials used were of geological origin and it was mixed with sodium-based alkaline solution, therefore the masonry adobes were name as geopolymer masonry units.

Embodied energy is the sum of all the energy required to produce a product i.e. total energy consumed to procure the raw materials, transport it, process it for the production of product, and manufacture the product. Quantification of embodied energy is usually done as a part of Life cycle Analysis (LCA). LCA involving embodied energy, operational energy and demolition energy is termed as "cradle-to-grave" analysis. On the other hand, the "cradle-to-gate" analysis is done to specify the embodied energy of building materials by aggregating all the energies up to the point of using them in a building. Table 1 provides the embodied energy of different building materials obtained by such analysis by various researchers.

The embodied energy for different building blocks has been presented in Table 2. Variation in embodied energy observed for masonry units with different structural system has been presented in Table 3 . These values are especially 
Table 1. Embodied energy of different building materials.

\begin{tabular}{ccc}
\hline Material & Unit & Energy (MJ/Unit) \\
\hline Cement [2] & $1 \mathrm{~kg}$ & 4.6 \\
Lime [2] & $1 \mathrm{~kg}$ & 5.63 \\
Burnt brick [2] & $1 \mathrm{Brick}$ & 4.25 \\
Lime-pozzolana cement [3] & $1 \mathrm{~kg}$ & 2.5 \\
$\mathrm{NaOH}[4]$ & $1 \mathrm{~kg}$ & 20.5 \\
$\mathrm{Na}_{2} \mathrm{SiO}_{3}[5]$ & $1 \mathrm{~kg}$ & 5.37
\end{tabular}

Table 2. Embodied energy of building blocks [6].

\begin{tabular}{ccc}
\hline Material & Size per unit $(\mathrm{mm})$ & $\begin{array}{c}\text { Embodied } \\
\text { Energy/Unit (MJ) }\end{array}$ \\
\hline Brick & $225 \times 108 \times 75$ & $4.63-5.6$ \\
Stabilised Mud Block & $230 \times 190 \times 100$ & 2.85 \\
Hollow Concrete Block & $400 \times 200 \times 200$ & 7.6 \\
Hollow Clay Block & $400 \times 200 \times 200$ & 16.7 \\
Cut Sandstone & $450 \times 230 \times 150$ & 7.55 \\
\hline
\end{tabular}

Table 3. Variation in EE observed for masonry units with different structural system [7].

\begin{tabular}{ccc}
\hline & \multicolumn{2}{c}{ Embodied Energy $\left(\mathrm{GJ} / \mathrm{m}^{2}\right)$} \\
\cline { 2 - 3 } Masonry Type & $\begin{array}{c}\text { Moment resisting } \\
\text { frame building }\end{array}$ & $\begin{array}{c}\text { Partly Load } \\
\text { bearing building }\end{array}$ \\
\hline $\begin{array}{c}\text { Autoclaved aerated } \\
\text { concrete Blocks } \\
\text { Solid block concrete }\end{array}$ & 2.76 & 2.21 \\
$\begin{array}{c}\text { Engineered Hollow Concrete } \\
\text { blocks-10\% cement } \\
\text { Table-moulded Bricks }\end{array}$ & 2.03 & 1.42 \\
Fly Ash Bricks & 1.96 & 1.35 \\
Stabilised Mud Blocks-8\% & 2.89 & 2.38 \\
cement & 2.66 & 2.12 \\
Hollow clay block & 1.85 & 1.25 \\
\hline
\end{tabular}

relevant for the materials used in and around Bengaluru, India.

\section{Present Study}

In the present investigation, Geopolymer-based masonry units were cast and tested for various strength parameters. The dimensions of units were similar to the dimensions of table moulded bricks. The size of unit was $230 \mathrm{~mm}$ length, 105 $\mathrm{mm}$ breadth and $75 \mathrm{~mm}$ height with frog on one side. As per Bureau of Indian Standard specification IS1077-1992 [8], the minimum wet compressive strength of bricks shall not be less than be $3.5 \mathrm{MPa}$. The mix proportions for the produc- 
tion of masonry units were selected based on the strength parameters of cubes studied during the development of the product. The mix proportions of cubes which gave wet compressive strength greater than $3.5 \mathrm{MPa}$ were selected for the production of masonry units. Tests were carried out on TBS-BP-L/LPC-based masonry in order to obtain the critical parameters required for design of masonry. They included 1) Compressive strength of masonry units, 2) Water absorption of masonry units, 3) Stress-strain characteristics of masonry units under compressive load, 4) Stress-strain behavior of stack-bonded masonry prisms under compressive load and 5) Shear bond strength of masonry triplets. The results indicated that they could be used as an alternative for conventional masonry.

The various raw materials used for casting masonry units and their mix proportions selected for unit production have been tabulated in Table 4. The concentration of the alkaline solution is also indicated.

\section{A Brief Background on Lime Pozzolana Cement}

According to IS 4098-1983 [9] lime pozzolana mixture is manufactured by "inter-grinding class $\mathrm{C}$ hydrated lime and pozzolana such as calcined clay or fly ash or rice husk ash in suitable proportions in a ball mill or tube mill or by blending ingredients in the form of fine powder". Further it states that "lime-pozzolana mixture which is essentially a mixture of lime and pozzolana could be used as an alternate cementing material to ordinary Portland cement for certain categories of work like masonry mortar and plaster, foundation concrete, levelling coarse under floors, road and airfield bases, precast building blocks (including light weight blocks), paving blocks, soil stabilization and as filler in water bound macadam in road construction". Lime based mortars, Lime-sand, Lime-Flyash, Lime surkhi based mortars has equivalent or more strength than cement based mortars. The lime based mortars are known to possess better properties in both plastic and hardened state; they have 1) reduced heat of hydration and thermal shrinkage, 2) increased workability and water retention and 3) relatively better strength of finished surface.

However, these days lime based mortar is primarily used in restoration of historic masonry buildings. In rural areas, lime is still produced traditionally and used in construction on a small-scale.

The lime made from burning of lime stone possessing good quantity of calcium

Table 4. Details of raw materials and their mix proportions.

\begin{tabular}{cccccc}
\hline$\#$ & Ingredients & $\begin{array}{c}\text { TBS50-B50 } \\
(7 \mathrm{M})\end{array}$ & $\begin{array}{c}\text { TBS65-B20-L15 } \\
(7 \mathrm{M})\end{array}$ & $\begin{array}{c}\text { TBS45-B45-LP10 } \\
(8 \mathrm{M})\end{array}$ & $\begin{array}{c}\text { TBS45-B45-LP10 } \\
(2 \mathrm{M})\end{array}$ \\
\hline 1 & TBS & 0.5 & 0.65 & 0.45 & 0.45 \\
2 & BP & 0.5 & 0.2 & 0.45 & 0.45 \\
3 & Lime (L) & - & 0.15 & - & - \\
4 & LPC & - & - & 0.1 & 0.1 \\
\hline
\end{tabular}


carbonate $\left(\mathrm{CaCO}_{3}\right)$ in a kiln, is generally known as hydraulic lime. This has a very low shelf life and it readily reacts with water and/or atmospheric moisture, carbon-di-oxide $\left(\mathrm{CO}_{2}\right)$ and renders itself unsuitable for binding applications. It would be useful if they are converted to a more stable form calcium hydroxide $\left(\mathrm{Ca}(\mathrm{OH})_{2}\right)$ using the well-known process of slaking. As a binding agent, slaked lime is nowhere comparable to cement. However a value added stable compound is the lime-pozzolana cement. This is a combination of pozzolana blended with lime in a well-defined manner. Jagdish et al. [10] have carried out extensive studies on production and use of lime-pozzolana cement. They describe two methods of production. The first method is production of "Pre-mixed" lime pozzolana cement while the second method is the production of in-situ lime-pozzolana cement. While the former method makes use of intensive mechanical energy, the latter uses thermal energy. In the present study, however, LPC has been produced in the laboratory in a similar way as hydraulic cement is produced i.e. by calcination of lime and clay in a specially designed kiln. Calcium carbonate was dry mixed with high clay content soil in 1:1 proportion (Yoganand et al.) [11]. Later, required quantity of water was added and wet mixed in grinder for 30 minutes. Later the prepared mix was spread on a glass plate and briquettes were made from the wet paste. Later the briquettes were allowed to dry. After drying, these briquettes were burnt in kiln at a temperature of $600^{\circ} \mathrm{C}$ to $900^{\circ} \mathrm{C}$ for 3 to 4 hours. Figure 1 show the flow chart for LPC production and Figure 2 shows the process of LPC production. The physical characteristics of the produced LPC was quantified based on the tests specified in IS 4098-1983 [9]. Table 5 gives the results and it can be noted that they conform to the requirements. The same has been used for production of TBS-BP-LPC based geopolymer bricks.

\section{Production of Geopolymer Masonry Units}

The preparation of solution, process of mixing, casting and curing have been done accordingly. The pictorial representation of production of masonry units have been given in Figure 2 .

The average compressive strength of all these units was well above the minimum strength of 3.5 MPa prescribed by IS1905-1987 [12]. The average water absorption values were well within the permissible limit of 20\% as per IS1077-1992 [8]. Thus, it can be concluded that all the masonry units were suitable for low-rise, load-bearing masonry applications practiced in India. It would be interesting to compare the compressive strength of these units with that of typical table moulded bricks (TMB) available in south India. The comparison is presented in Table 6.

\section{Embodied Energy Computation}

One of the approaches to assess the influence of the materials on environment is by carrying out life cycle energy assessment (LCA). The primary step in this process is to compute the embodied energy of the building products. There are a 

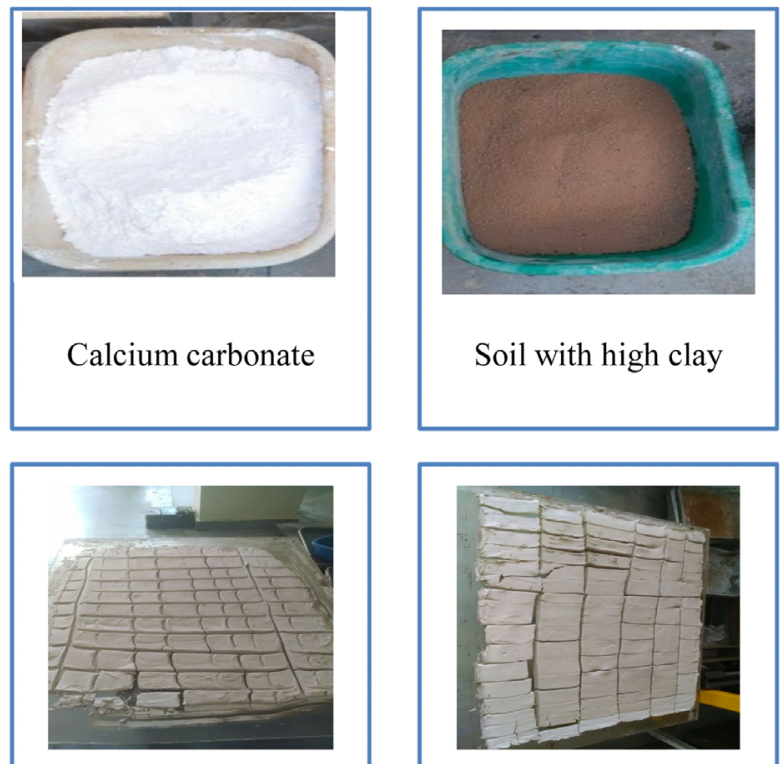

Prepared Briquettes

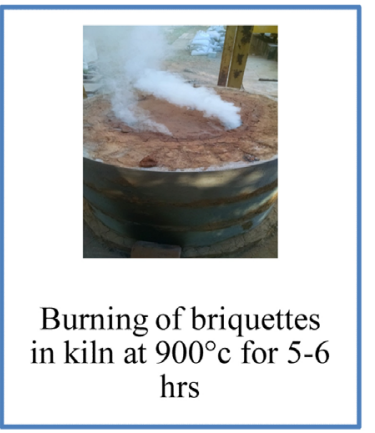

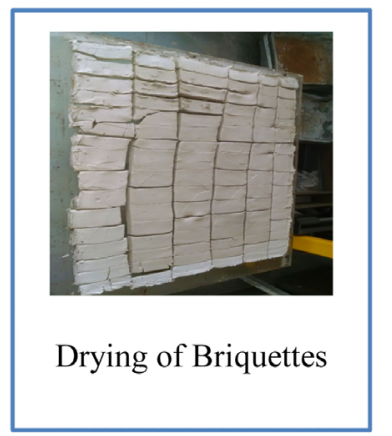

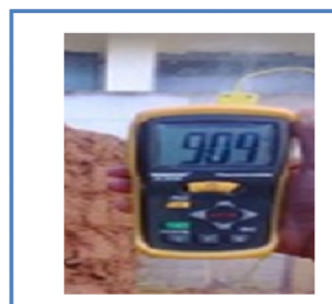

Temperature recording at regular intervals
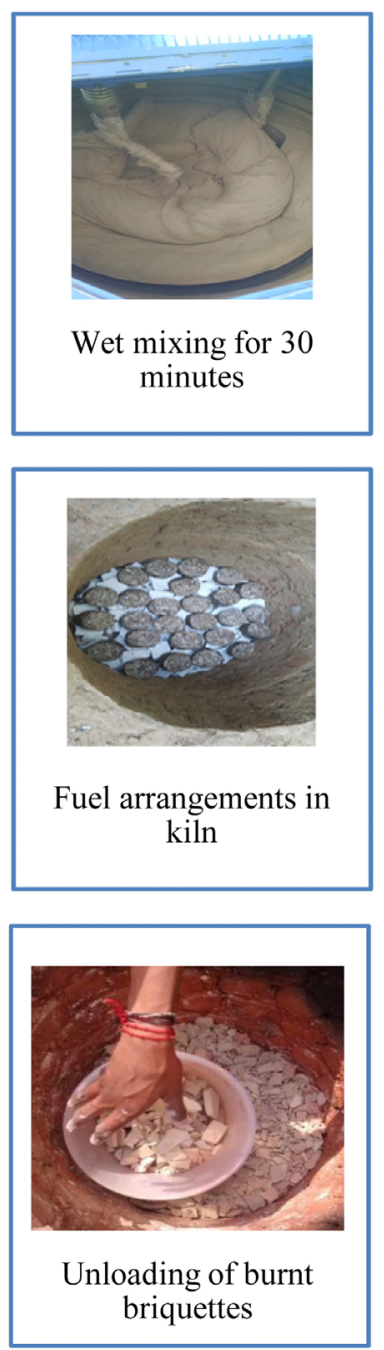

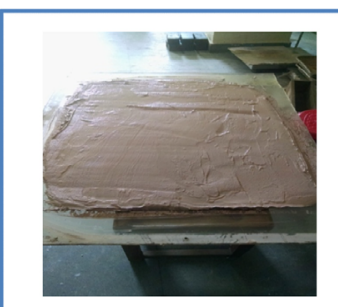

Spreading of wet mix on glass plate
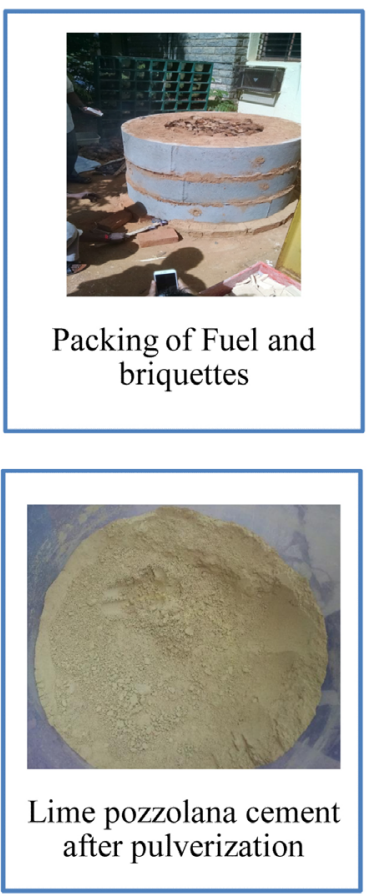

Figure 1. Pictorial representation of LPC production process.

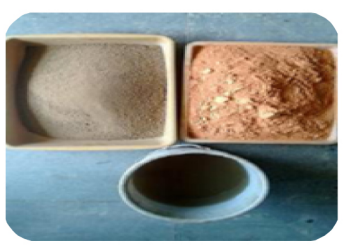

(a) Ingredients for masonry units

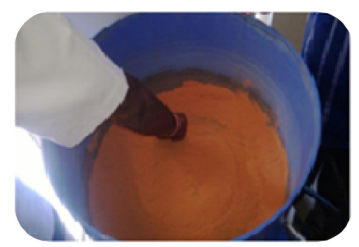

(b) Dry mixing of ingredients

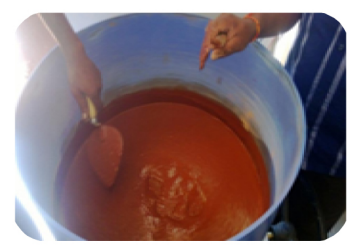

(c) Wet mixing of ingredients

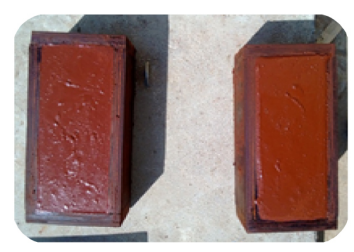

(d) Ingredients in

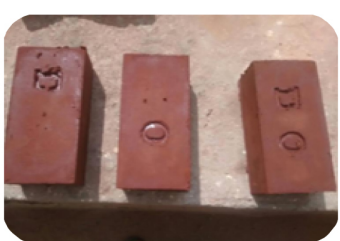

(e) Units under ambient curing

Figure 2. Pictorial representation of production of masonry units. 
Table 5. Physical characteristics of LPC as per IS 4098-1983 [9].

\begin{tabular}{|c|c|c|c|}
\hline \# & Parameters tested & Values & Requirements \\
\hline & Specific gravity & 2.58 & \\
\hline & Fineness by air permeability Test & $844.6 \mathrm{~kg} / \mathrm{m}^{2}$ & Minimum $250 \mathrm{~kg} / \mathrm{m}^{2}$ \\
\hline & Initial Setting time & 4 hours & Minimum 2 hours \\
\hline & Final setting time & 24 hours & Maximum 48 hours \\
\hline & Normal consistency & $80 \%$ & - \\
\hline & Soundness Test & - & - \\
\hline & $\begin{array}{l}7 \text { days Average wet compressive strength } \\
\text { of mortar cubes of } 50 \mathrm{~mm} \text { size } \\
\text { (1LPC: } 3 \text { Sand) }\end{array}$ & $0.73 \mathrm{MPa}$ & $\begin{array}{c}\text { Minimum } 0.3 \mathrm{MPa} \text { for LP7 } \\
\text { grade LPC }\end{array}$ \\
\hline & $\begin{array}{l}28 \text { days Average wet compressive strength } \\
\text { of mortar cubes of } 50 \mathrm{~mm} \text { size } \\
\text { (1LPC: } 3 \text { Sand) }\end{array}$ & & $\begin{array}{c}\text { Minimum } 0.7 \mathrm{MPa} \text { for LP7 } \\
\text { grade LPC }\end{array}$ \\
\hline
\end{tabular}

Table 6. Compressive strength of GP masonry units compared with TMB.

\begin{tabular}{cccc}
\hline$\#$ & $\begin{array}{c}\text { Type of geopolymer } \\
\text { masonry unit }\end{array}$ & $\begin{array}{c}\text { Quantity of alkaline } \\
\text { solution required } \\
\text { (based on flow test) }\end{array}$ & $\begin{array}{c}\text { Mean compressive } \\
\text { strength (MPa) }\end{array}$ \\
\hline 1 & $\mathrm{TBS}_{50}-\mathrm{B}_{50}(7 \mathrm{M})$ & $30 \%$ & 7.41 \\
2 & $\mathrm{TBS}_{65}-\mathrm{B}_{20}-\mathrm{L}_{15}(7 \mathrm{M})$ & $18 \%$ & 7.95 \\
3 & $\mathrm{TBS}_{45}-\mathrm{B}_{45}-\mathrm{LP}_{10}(8 \mathrm{M})$ & $30 \%$ & 17.36 \\
4 & $\mathrm{TBS}_{45}-\mathrm{B}_{45}-\mathrm{LP}_{10}(2 \mathrm{M})$ & $30 \%$ & 13.5 \\
5 & $\mathrm{TMB}[8]$ & - & 6.0 \\
\hline
\end{tabular}

number of factors that affect the embodied energy of building materials viz., availability and process of extraction of raw materials, geographic location, distance and mode of transportation to the processing site, type and efficiency of machinery used for processing and distance from which material is to be procured for construction. The method adopted for embodied energy calculation, validity and accuracy of the data compiled plays a crucial role in LCA. There could be "cradle-to-grave", "cradle-to-site" or even "cradle-to-gate" type of EE assessment depending upon the requirement. In the present study the end product i.e. the geopolymer masonry units are made at site using the adobe process; hence the cradle-to-site analysis has been carried out.

For the purpose of computing embodied energy, the energy required for certain processes from the present study have been computed based on the fuel/electrical energy associated with the process. For some of the materials which have been procured, such as lime, alkaline solutions etc, the embodied energy from literature have been taken [4] [5]. The energy expended from the manual efforts, such as sieving, mixing, placing in the mould etc, has not been considered.

Table 7 provides the description and calculation of the embodied energy of 
Table 7. Embodied energy computation for production of TBS-BP-L/LPC geopolymer masonry units.

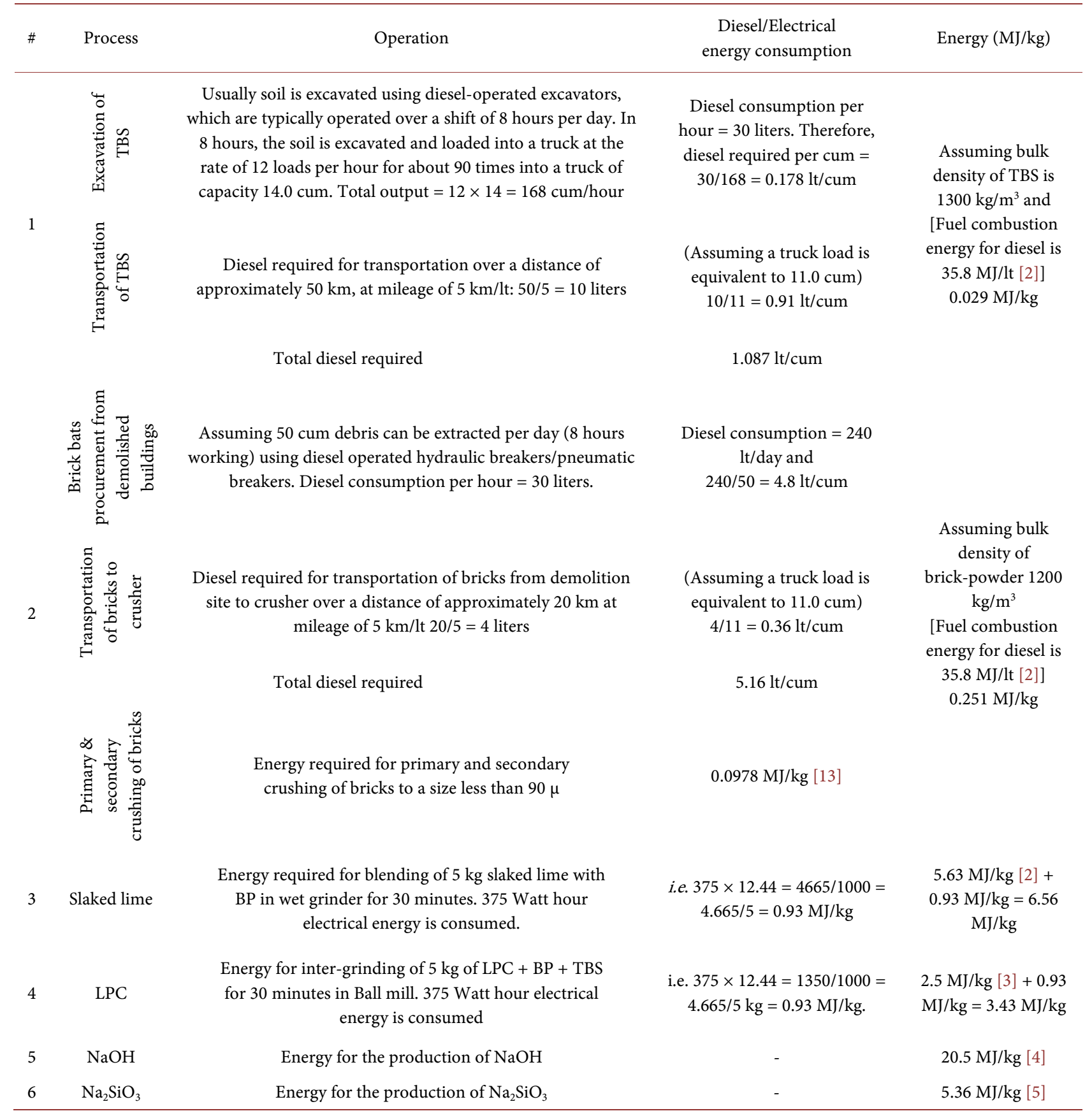

the ingredients of TBS-BP-L/LPC based geopolymer masonry units.

\section{Results and Discussions}

The Embodied energy of the four types of TBS-BP-L/LPC-based geopolymer masonry units of size $230 \times 105 \times 75 \mathrm{~mm}$ (i.e., the size of typical table-moulded bricks) has been presented in Table 8 . The table also provides the cost comparison and their respective compressive strength.

It would be pertinent to look at the main contributors to $\mathrm{EE}$ and cost of each 
Table 8. Comparative analysis for TBS-BP-L/LPC geopolymer masonry units and table moulded bricks.

\begin{tabular}{ccccccc}
\hline$\#$ & Samples & $\begin{array}{c}\text { Avg. } \\
\text { compressive } \\
\text { strength } \\
(\mathrm{MPa})\end{array}$ & $\begin{array}{c}\text { EE } \\
(\mathrm{MJ} / \mathrm{unit})\end{array}$ & $\begin{array}{c}\text { EE per unit } \\
\text { compressive } \\
\text { strength } \\
(\mathrm{MJ} / \mathrm{MPa})\end{array}$ & $\begin{array}{c}\text { Cost } \\
\text { (INR/unit) }\end{array}$ & $\begin{array}{c}\text { Cost per unit } \\
\text { compressive } \\
\text { strength } \\
\text { (INR/MPa) }\end{array}$ \\
\hline 1 & TBS50-B50 (7M) & 7.41 & 4.74 & 0.63 & 12.17 & 1.64 \\
2 & $\begin{array}{c}\text { TBS65-B20-L15 (7M) } \\
3\end{array}$ & 7.95 & 6.44 & 0.81 & 11.32 & 1.42 \\
& $\begin{array}{c}\text { TBS45-B45-LP10 } \\
(8 M)\end{array}$ & 17.36 & 6.5 & 0.37 & 17.55 & 1.01 \\
4 & $\begin{array}{c}\text { TBS45-B45-LP10 } \\
(2 \mathrm{M})\end{array}$ & 13.5 & 5.06 & 0.37 & 17.15 & 1.27 \\
5 & TMB [8] & 6.0 & 4.25 & 0.71 & 6.00 & 1.00 \\
\hline
\end{tabular}

unit. Table 3 shows the quantity of the ingredient materials used in each of the 4 types of masonry units. The EE and cost of each material is also provided. It has to be noted that the EE and cost of grinding has also been included. The comparison clearly reveals that table moulded brick has the least EE amongst the five types of masonry units. The embodied energy of GP masonry units made without lime or LPC was the minimum (4.74 MJ/unit) among the remaining four and this is marginally more than that of the EE of TMB.

The addition of lime or LPC has only increased the EE values. Expectedly, addition of the binders and alkaline solution has led to higher cost as well. However, the addition of these materials is not without any benefits. They have indeed contributed to the enhanced compressive strength. It would now be interesting to look at the EE benefits of TBS-BP-based GP units in terms of relative strength. The EE of each masonry unit is normalized with respect to its compressive strength and presented in Table 8. This comparison appears encouraging and clearly indicates that the blocks made by using LPC ( $8 \mathrm{M}$ and $2 \mathrm{M})$ possess the least EE per unit compressive strength $(0.37 \mathrm{MJ} / \mathrm{MPa})$, which is nearly half of that of TMB.

Similarly, the cost of each masonry unit has been normalized with respect to its compressive strength. It can be observed that $\mathrm{TBS}_{45}-\mathrm{B}_{45}-\mathrm{LP}_{10}(8 \mathrm{M})$ bricks were comparable in cost to that of table-moulded bricks looked at from the units of cost per unit strength.

The graphical comparison of the EE of the four types of GP blocks is shown in Figure 3. Embodied energy and compressive strength comparison is shown in Figure 4. The comparison indicates that the bulk contributors are the alkaline materials, especially $\mathrm{Na}_{2} \mathrm{SiO}_{3}$. The major contributor for cost is also alkaline materials; again the bulk is from $\mathrm{Na}_{2} \mathrm{SiO}_{3}$. It can, hence, be concluded that any further improvements in the development of GP masonry units using TBS-BP should have to keep the issue of energy and cost contribution of $\mathrm{NaOH}$ and $\mathrm{Na}_{2} \mathrm{SiO}_{3}$. This is possible by using alkaline solutions at lower concentration and reduced $\mathrm{NaOH}: \mathrm{Na}_{2} \mathrm{SiO}_{3}$ ratio. Perhaps using locally available ingredients which 


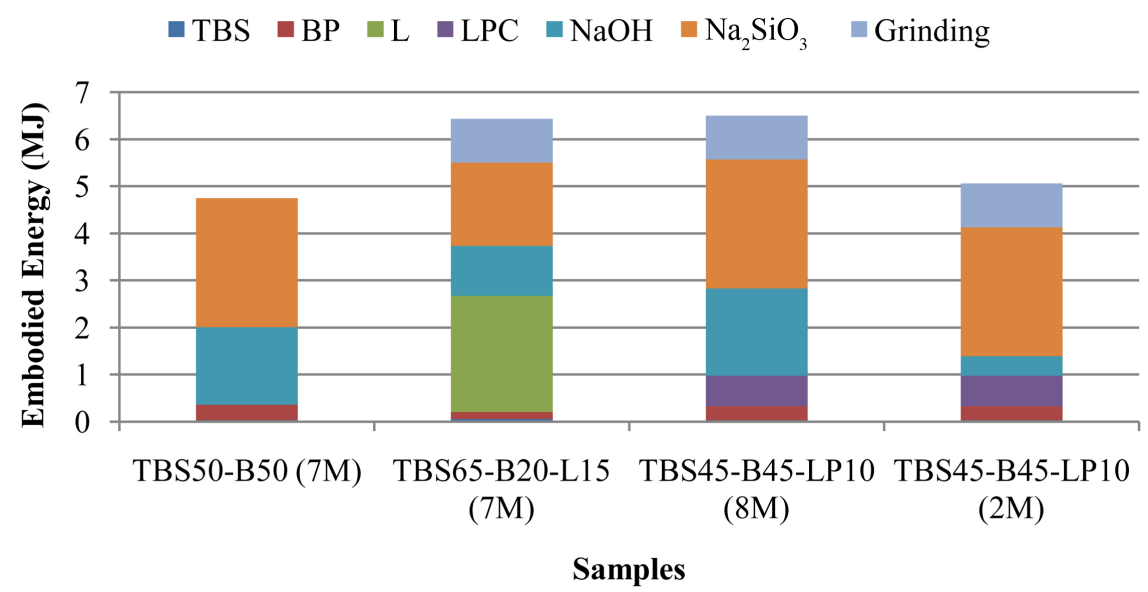

Figure 3. Embodied energy contribution material breakup.
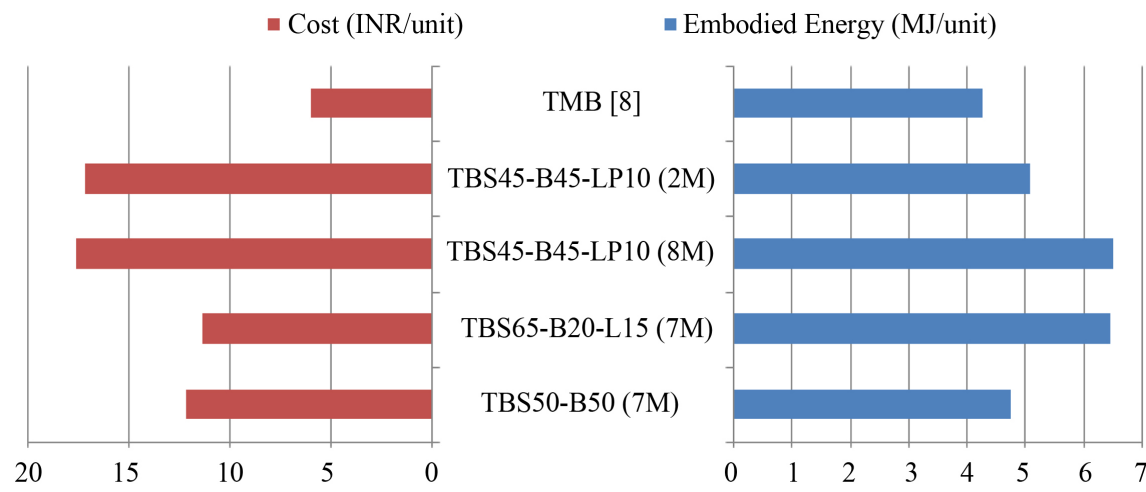

Figure 4. Comparison between embodied energy and cost of masonry units.

possess reactive silica may lead to dispensing with the use of $\mathrm{Na}_{2} \mathrm{SiO}_{3}$ and thus contribute to energy and cost benefits. Further studies are being undertaken in this direction.

\section{Concluding Remarks}

The followings are the highlights of embodied energy computations:

- The embodied energy of GP masonry units made without lime or LPC was the minimum among the four, which was $4.74 \mathrm{MJ}$ /unit. This EE (embodied energy) value is comparable to that of similar-sized, table-moulded bricks of south India; however, the strength of GP units was better than that of TMBs of south India. The EE values of the other GP units ranged from 5.06 to 6.5 MJ/unit.

- The cost comparison trends were also along similar lines as that of EE. All the masonry units were significantly expensive when compared to the cost of similar-sized TMBs. Again, the major contributors were $\mathrm{NaOH}$ and $\mathrm{Na}_{2} \mathrm{SiO}_{3}$. It is evident that reducing molarity and ratio of $\mathrm{NaOH}: \mathrm{Na}_{2} \mathrm{SiO}_{3}$ should to be the next steps in reaping the benefits of energy and cost.

- In terms of relative strength, embodied energy of each type of masonry unit 
per unit compressive strength was favorable when compared to that of table-moulded bricks of south India.

- It could be concluded that any further improvements in the development of GP masonry units using TBS-BP should keep the issue of energy and cost contribution of $\mathrm{NaOH}$ and $\mathrm{Na}_{2} \mathrm{SiO}_{3}$.

\section{References}

[1] Davidovits, J. (1988) Geopolymer Chemistry and Properties. Geopolymer, 88, 125-148.

[2] Maïni, S. and Thautam, V. (2013) Embodied Energy of Various Materials and Technologies. Auroville Earth Institute, A Data Compilation.

[3] Manjit, S. (2012) Energy and Environmental Concerns in Building Materials. National Conference on Emerging Trends of Energy Conservation in Buildings. Central Building Research Institute, Roorkee.

[4] Tempest, B., Sanusi, O., Gergely, J., Ogunro, V. and Weggel, D. (2009) Compressive Strength and Embodied Energy Optimization of Fly Ash-Based Geopolymer Concrete. World of Coal Ash (WOCA) Conference.

[5] Fawer, M., Concannon, M. and Rieber, W. (1999) Life Cycle Inventories for the Production of Sodium Silicates. The International Journal of Life Cycle Assessment, 4, 207-212. https://doi.org/10.1007/BF02979498

[6] Surekha, B., Hegde, M.N. and Jagadish, K.S. (2016) Energy and Building Materials. International Journal of Civil Engineering, 5, 13-24.

[7] Varsha, B.N., Raghunath, S. and Keshava, M. (2017) Influence of Choice of Structural System \& In-Fill Masonry on the Embodied Energy \& Cost of a Low-Rise Residential Urban-Building Indian Case Study. Open Journal of Energy Efficiency, 6, 41-60.

[8] IS1077-1992 (2007) Common Burnt Clay Building Bricks-Specification. Bureau of Indian Standards, New Delhi.

[9] IS: 1498-1970. Indian Standard Code of Practice for Soil Classification. 3rd Edition, Bureau of Indian Standards, New Delhi.

[10] Jagadish, K.S. and Yogananda, M.R. (1984) Production of Alternative Cements for Rural Applications. Proceedings of Regional Seminar on Farm Machinery and Rural Industries, Chulalongkorn University, Bangkok.

[11] Yogananda, M.R., Jagadish, K.S. and Kumar, R. (1983) Studies on Surkhi and Rice Husk Ash Pozzolana. ASTRA, IISc, Bengaluru.

[12] IS: 1905-1987 (2002) Indian Standard Code of Practice for Structural Use of Unreinforced Masonry. 3rd Edition, Bureau of Indian Standards, New Delhi.

[13] Saranya, S. (2016) Quantification of Embodied Energy for Both Coarse and Fine Aggregates. MTech Thesis, Department of Civil Engineering, BMS College of Engineering, Bengaluru. 


\section{Notations}

TBS-Tank-bed soil,

BP-Brick-powder,

L-Lime,

LPC-Lime-pozzolana-cement,

GP-Geopolymer.

Submit or recommend next manuscript to SCIRP and we will provide best service for you:

Accepting pre-submission inquiries through Email, Facebook, LinkedIn, Twitter, etc. A wide selection of journals (inclusive of 9 subjects, more than 200 journals)

Providing 24-hour high-quality service

User-friendly online submission system

Fair and swift peer-review system

Efficient typesetting and proofreading procedure

Display of the result of downloads and visits, as well as the number of cited articles

Maximum dissemination of your research work

Submit your manuscript at: http://papersubmission.scirp.org/

Or contact ojee@scirp.org 